\title{
IMPLEMENTASI SISTEM PENJUALAN BERBASIS E-COMMERCE UNTUK MENINGKATKAN PENDAPATAN PADA TOKO XYZ COLLECTION
}

\author{
Louisa Eunike Sihotang ${ }^{1)}$, Agus Umar Hamdani ${ }^{2)}$ \\ ${ }^{1}$ Sistem Informasi, Fakultas Teknologi Informasi, Universitas Budi Luhur \\ ${ }^{1,2} \mathrm{Jl}$. Raya Ciledug, Petukangan Utara, Kebayoran Lama, Jakarta Selatan 12260

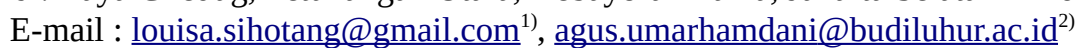

\begin{abstract}
Abstraksi
Toko XYZ Collection merupakan sebuah badan usaha yang bergerak di bidang penjualan perlengkapan baju gamis dan pengantin serta barang-barang pendukung lainnya dan berlokasi di ITC Cipulir Jakarta Selatan. Saat ini aktivitas penjualan dan pengolahan data yang masih dilakukan secara manual, toko tersebut juga belum maksimal dalam memanfaatkan perangkat teknologi informasi untuk mendukung penjualan terdapat beberapa kendala bisnis, seperti: kurangnya promosi sehingga produk yang ditawarkant tidak dikenal pelanggan, stok barang yang tidak terpantau yang mengakibatkan barang dengan model lama susah untuk terjual kembali, laporan penjualan yang masih menjadi satu dengan pendapatan yang mengakibatkan setiap laporan belum memiliki data yang valid. Berdasarkan kondisi bisnis yang terjadi pada Toko XYZ Collection,, maka diperlukan adanya sistem yang membantu menyelesaikan setiap permasalahan diatas. Oleh karena itu, peneliti melakukan penelitian guna membantu permasalahan yang terjadi pada Toko XYZ Collection dengan membangun aplikasi E-commerce. Beberapa metodologi yang digunakan dalam penelitian ini, antara lain: analisis model bisnis menggunakan Business Model Canvas, analisis masalah menggunakan pendekatan Fishbone Diagram, analisis sistem berjalan dan sistem E-Commerce menggunakan Unified Modeling Language (UML), implementasi sistem E-Commerce menggunakan bahasa pemrograman PHP dengan database MySQL, teknik Search Engine Optimization menggunakan pendekatan White-Hat SEO dan strategi pemasaran menggunakan AARRR Framework. Hasil akhir dari penelitian ini adalah aplikasi E-Commerce yang dapat membantu Toko XYZ Collection meningkatkan pendapatan melalui fitur promosi dan fitur penjualan barang secara online.
\end{abstract}

Kata kunci: E-Commerce, Produk Baju Gamis dan Pengantin, PHP, Search Engine Optimization, AARRR Framework.

\section{PENDAHULUAN}

Perkembangan era digitalisasi sekarang ini teknologi informasi memberikan pengaruh yang sangat besar dan merambah hampir ke seluruh lapisan masyarakat dan juga bidang usaha. Pengaruh yang paling nyata terlihat pada terjadinya perubahan mendasar terhadap cara orang melakukan komputasi, terutama yang diimplementasikan dalam penggunaan internet dalam dunia bisnis berbasis online. E-Commerce adalah suatu proses berbisnis dengan menggunakan teknologi elektronik yang menghubungkan antara perusahaan, konsumen, dan masyarakat dalam bentuk transaksi elektronik. Transaksi elektronik biasanya menggunakan teknologi internet. Dengan adanya internet, maka proses jual beli yang di lakukan secara online sehingga membuat lapisan masyarakat enggan untuk melakukan proses belanja atau jual beli dengan datang ke toko melainkan hanya dengan gadget. Toko XYZ Collection adalah sebuah toko yang menjual baju gamis dan pengantin serta perlengkapannya yang melakukan penjualan secara manual yang menyebabkan beberapa kendala dalam proses bisnisnya. Beberapa hasil penelitian yang sudah dilakukan oleh peneliti sebelumnya yang menjadi rujukan, antara lain: penelitian membahas permasalahan mengenai proses penjualan dan pemasaran produk menggunakan aplikasi berbasis web menggunakan bahasa pemrograman PHP, penelitian membahas pemanfaatan web ECommerce untuk meningkatkan strategi pemasaran pada produk UMKM menggunakan bahasa pemrogram PHP versi 5.4.x, penelitian membahas pemanfaatan E-Commerce untuk memperluas pemasaran produk furniture mengunakan bahasa pemrograman PHP dengan framework CodeIgniter, Netbean IDE versi 7.2 dan menggunakan aplikasi Navicat Premium untuk merancang basis data, penelitian membahas mengenai implementasi $E$ Commerce, implementasi teknik Search Engine Optimization (SEO) dan implementasi strategi pemasaran (marketing) 4P (Product, Price, Promotion and Place) menggunakan Content Management System Wordpress pada toko aksesoris motor. Berdasarkan kondisi bisnis dan studi literature diatas, maka peneliti melakukan penelitian untuk membuat model E-Commerce yang sesuai dengan kebutuhan Toko XYZ Collection. Perbedaan 
antara penelitian yang peneliti lakukan dengan penelitian sebelumnya terletak pada penggunakan Content Management System, teknik Search Engine Optimization dan implementasi strategi pemasaran menggunakan AARRR Framework. Adapun rumusan masalah yang harus dijawab dalam penelitian ini adalah bagaimana model E-Commerce dalam rangka meningkatkan pendapatan pada Toko XYZ Collection. Manfaat dari penelitian ini adalah membangun hubungan interaksi dalam transaksi penjualan menggunakan antar muka dan dilakukan secara online.

\section{METODE PENELITIAN}

Penelitian ini adalah penelitian terapan (Applied Research), dimana penelitian diawali dengan melakukan analisis sistem berjalan secara kuantitatif, kemudian dilakukan dan perancangan sistem sesuai hasil analisis tersebut. Tahapantahapan penelitian dapat dilihat pada gambar 1 berikut ini.

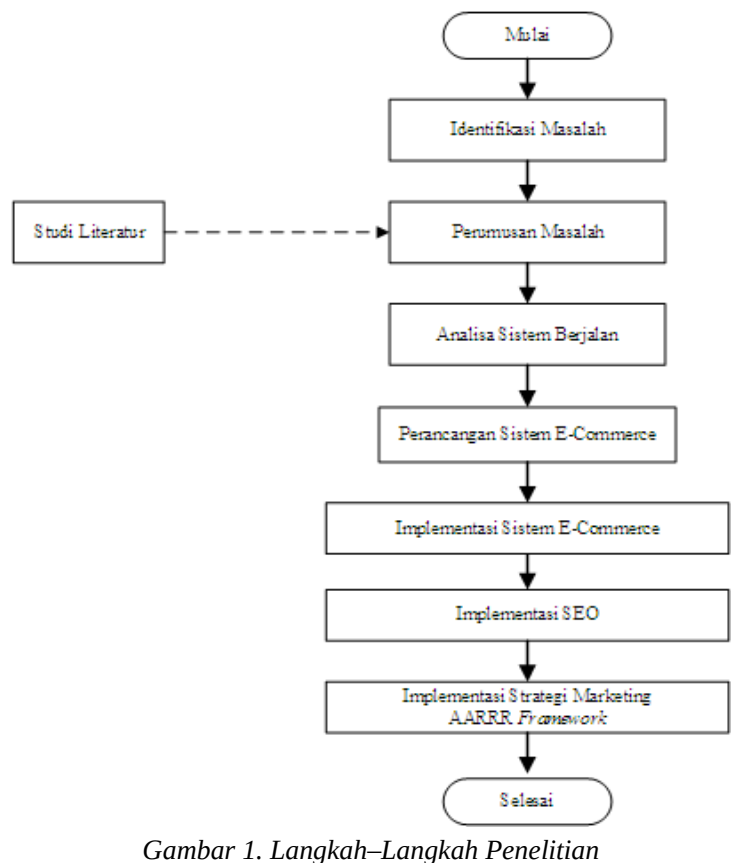

Berdasarkan gambar 1, maka berikut ini penjelasan mengenai tahapan-tahapan penelitian: Tahap mulai: peneliti melakukan observasi terhadap kondisi bisnis dan kondisi penggunaan teknologi informasi yng ada di instansi saat ini, Tahap identifikasi masalah: untuk mengidentifikasi masalah pada Toko XYZ Collection, peneliti menggunakan pendekatan model Fishbone Diagram. Fishbone Diagram digunakan untuk mengetahui akibat dari suatu masalah, dicari beberapa kemungkinan penyebabnya, kemudian selanjutnya diambil tindakan. Adapun analisis Fishbone Diagram yang digunakan adalah konsep 7P (Process, Place, Price, Product, Physical Evidence, Productivity and Quality). Tahapan ketiga studi literature, peneliti melakukan review studi literatur terhadap topik penelitian yang sesuai, Tahap keempat, peneliti membuat rumusan masalah yang harus dijawab pada penelitian ini, Tahap kelima analisis sistem berjalan: peneliti melakukan analisis model bisnis menggunakan Business Model Canvas (BMC), menurut Frans Royan, Business Model Canvas merupakan kerangka kerja (frame work) untuk memetakan bisnis kita agar kinerjanya lebih optimal. Kemudian membuat analisis model proses bisnis menggunakan model Activity Diagram, dan membuat tabel identifikasi kebutuhan sistem usulan, Tahap keenam perancangan model E-Commerce, adapun pendekatan yang digunakan adalah Unified Modeling Language (UML). Unified Modeling Language (UML) adalah bahasa pemodelan untuk sistem dan perangkat lunak yang berparadigma berorientasi obyek, pemodelan tersebut digunakan untuk menyederhanakan masalah yang kompleks sehingga lebih mudah untuk dipelajari dan dipahami . Adapun diagram yang digunakan adalah Activity Diagram, Use Case Diagram dan Class Diagram, Tahap ketujuh, penulis membangun website E-Commerce menggunakan Content Management System Wordpress. Tahap kedelapan implementasi teknik Search Engine Optimation (SEO), SEO adalah teknik pencarian yang menggunakan kata kunci atau frase yang mengandung indikator yang terkandung dalam halaman-halaman web dan informasi tesebut akan diindeks oleh mesin pencari. Peneliti menggunakan pendekatan White-Hat SEO dengan teknik Onpage, Tahap kesembilan implementasi strategi AARRR Framework. AARRR Framework adalah sebuah model yang digunakan untuk mengukur keberhasilan sebuah produk startup. AARRR terdiri dari 5 (lima) kompnen, yaitu Acquisition (strategi mendapatkan pelanggan baru), Activation (bagaimana pengalaman pelanggan dalam menggunakan produk), Retenion (apakah pelanggan akan kembali menggunakan produk), Revenue (stategi mendapatkan keuntungan) dan Referral (apakah pelanggan akan menyarankan produk ke orang lain. Peneliti mengimplementasikan strategi AARRR Framework guna menunjang pemasaran dan promosi produk yang ada pada Toko XYZ Collection. Tahap selesai, peneliti melakukan evaluasi dan menarik kesimpulan dari hasil analisa, perancangan dan implementasi sistem E-Commerce pada Toko XYZ Collection. 
3. HASIL DAN PEMBAHASAN

3.1. Analisis Model Bisnis dengan Business Model Canvas

Berikut ini hasil analisis model bisnis pada Toko XYZ Collection yang dapat dilihat pada tabel 1 berikut ini.

Tabel 1. Hasil Analisis Business Model Canvas

\begin{tabular}{|c|c|}
\hline Komponen BMC & Hasil Analisis \\
\hline Value Propositions & $\begin{array}{l}\text { Barang yang di jual yaitu model baju } \\
\text { yang di jual hanya ada di Rara } \\
\text { Collection saja dan dipatenkan dengan } \\
\text { brand/tag pada baju yang bertuliskan } \\
\text { Rara Collection. }\end{array}$ \\
\hline Activities Key & Pembelian barang \\
\hline Resources Key & Quality Control Staff. \\
\hline Partner Key & Bank, kurir dan wedding organizer. \\
\hline Customer Segments & $\begin{array}{l}\text { Komunitas pengajian, panitia wedding } \\
\text { organizer serta calon pengantin. }\end{array}$ \\
\hline Customer Relationship & $\begin{array}{l}\text { Memberikan diskon serta memberikan } \\
\text { penawaran harga. }\end{array}$ \\
\hline Channel & $\begin{array}{l}\text { Saluran whatsapp, facebook dan } \\
\text { instagram, website, marketplace dan E- } \\
\text { Commerce }\end{array}$ \\
\hline Cost Structures & $\begin{array}{l}\text { biaya sewa toko, gaji karyawan, } \\
\text { pembelian baju yang akan dijual, } \\
\text { transport pengantaran barang ke toko, } \\
\text { serta biaya web }\end{array}$ \\
\hline$\underline{\text { Revenue Streams }}$ & Pendapatan penjualan. \\
\hline
\end{tabular}

Adapun model Business Model Canvas pada Toko XYZ Collection dapat dilihat pada gambar 2.

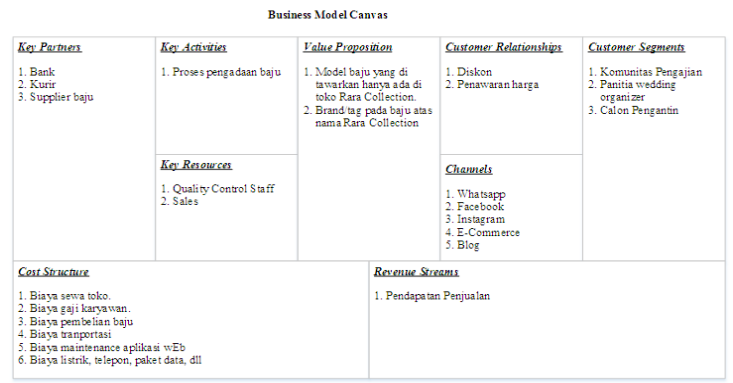

Gambar 2. Analisis Business Model Canvas

\subsection{Analisis Masalah dengan Fishbone Diagram}

Berikut ini hasil analisis masalah pada Toko XYZ Collection mengunakan pendekatan Fishbone Diagram yang dapat dilihat pada gambar 3.

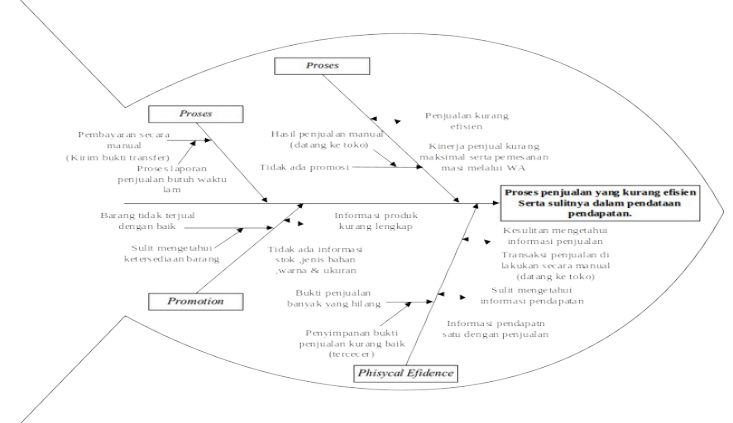

Gambar 3. Analisis Fishbone Diagram
Tabel 2 berisi hasil analisis malah dan identifikasi kebutuhan system usulan / solusi yang ditawarkan.

Tabel 2. Identifikasi Kebutuhan Sistem / Solusi

\begin{tabular}{|c|c|c|}
\hline Masalah & Penyebab & $\begin{array}{l}\text { Identifikasi } \\
\text { Kebutuhan / Solusi }\end{array}$ \\
\hline $\begin{array}{l}\text { Barang tidak } \\
\text { dikenali pelanggan. }\end{array}$ & Kurangnya promosi. & $\begin{array}{l}\text { Sistem harus } \\
\text { menyediakan fitur } \\
\text { promosi barang. }\end{array}$ \\
\hline $\begin{array}{l}\text { Sulit mengetahui } \\
\text { ketersediaan barang }\end{array}$ & $\begin{array}{l}\text { Stok barang tidak } \\
\text { terpantau. }\end{array}$ & $\begin{array}{l}\text { Sistem harus bisa } \\
\text { menampilkan } \\
\text { informasi stok barang. }\end{array}$ \\
\hline $\begin{array}{l}\text { Proses pemesanan } \\
\text { tidak efektif }\end{array}$ & $\begin{array}{l}\text { Transaksi pemesanan } \\
\text { harus datang ke toko. }\end{array}$ & $\begin{array}{l}\text { Sistem harus bisa } \\
\text { menyediakan fitur } \\
\text { pemesanan secara } \\
\text { online. }\end{array}$ \\
\hline $\begin{array}{l}\text { Kesulitan } \\
\text { mengetahui } \\
\text { informasi penjualan }\end{array}$ & $\begin{array}{l}\text { Informasi pendapatan } \\
\text { masih menjadi satu } \\
\text { dengan informasi } \\
\text { penjualan }\end{array}$ & $\begin{array}{l}\text { Sistem harus bisa } \\
\text { menampilkan } \\
\text { informasi pendapatan. }\end{array}$ \\
\hline $\begin{array}{l}\text { Kesulitan } \\
\text { mengetahui } \\
\text { informasi } \\
\text { pendapatan }\end{array}$ & $\begin{array}{l}\text { Belum ada laporan } \\
\text { pendapatan }\end{array}$ & $\begin{array}{l}\text { Sistem harus bisa } \\
\text { menampilkan } \\
\text { informasi pendapatan. }\end{array}$ \\
\hline
\end{tabular}

3.3. Analisis Proses Bisnis Usulan

1. Activity Diagram Pemesanan Barang

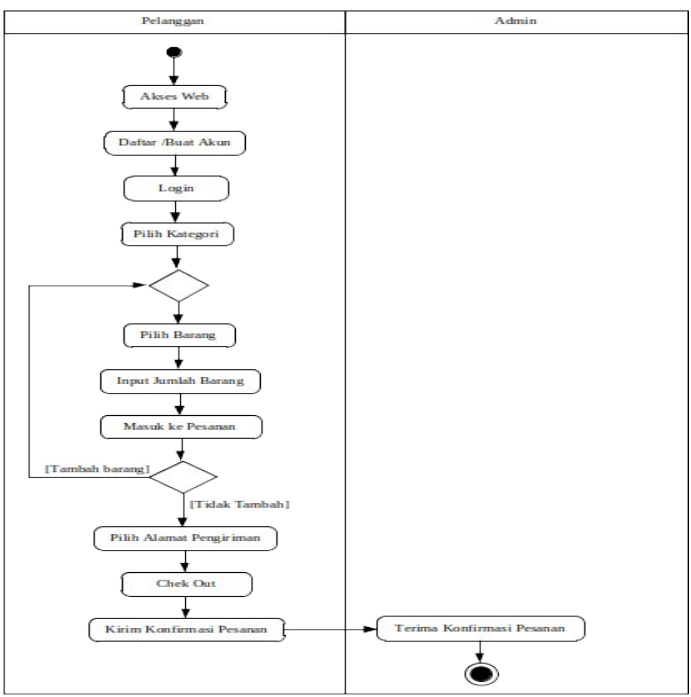

Gambar 4. Activity Diagram Pemesanan Barang

Gambar 4 merupakan penjelasan dari proses pemesanan barang, yaitu di mulai dari pelanggan harus melakukan register terlebih dahulu jika pelanggan belum memiliki akun, tetapi jika pelanggan sudah memiliki akun pelanggan hanya cukup dengan login saja maka pelanggan sudah dapat melakukan pemesanan barang.

2. Activity Diagram Pembayaran

Pada proses ini pelanggan harus tetap melakukan login terlebih dahulu, setelah itu barulah pelanggan dapat masuk kepada konfirmasi pembayaran serta melihat detail barang yang sudah 
di pesan. Untuk mengkonfirmasi pembayaran pelanggan haruslah menguplod bukti pembayaran yang sudah di bayarkan sesuai pada detail pesanan. Aktivitas ini digambarkan pada gambar 5.

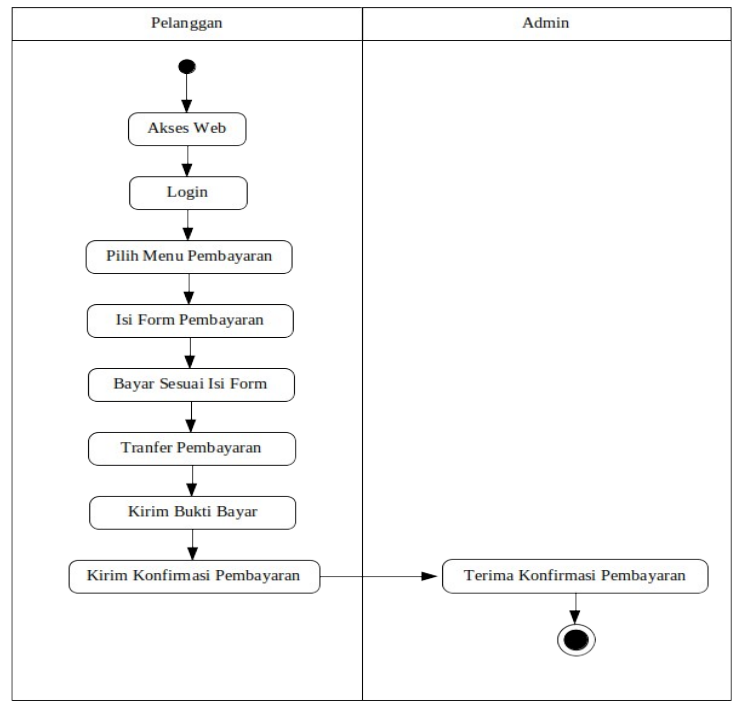

Gambar 5. Activity Diagram Pembayaran

\subsection{Pemodelan Sistem Usulan Menggunakan Use Case Diagram}

Berdasarkan pada proses bisnis usulan, dapat digambarkan model fungsionalitas sistem usulan menggunakan use case diagram sebagai berikut :

a. Use Case Diagram Master

Pada gambar ini merupakan gambar use case diagram master yang berisikan entry data barang, entry data pelanggan dan entry data kategori, yang dapat dilihat pada gambar 5 .

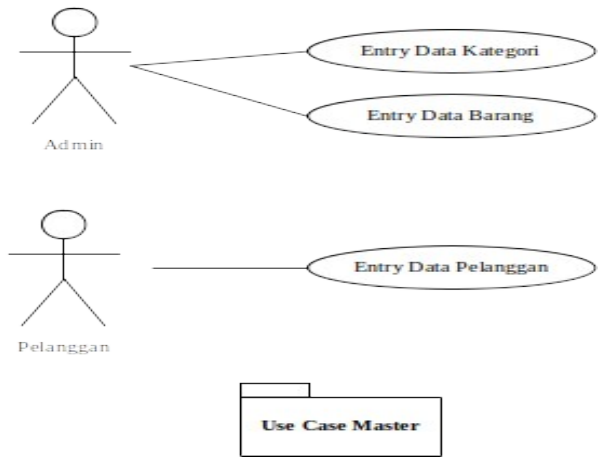

Gambar 6. Use Case Diagram Master

b. Use Case Diagram Transaksi

Pada Use Case Diagram Transaksi terdapat input entry pesanan, entry pengiriman, entry pembayaran dan entry penerimaan barang, yang dapat dilihat pada gambar 7 berikut ini.

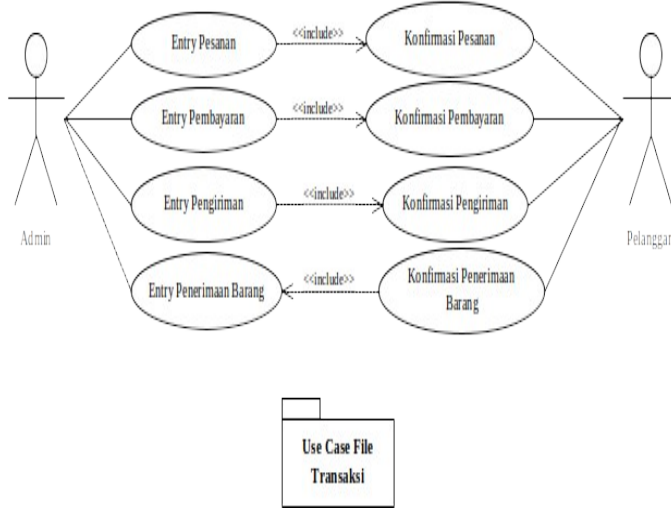

Gambar 7. Use Case Diagram Transaksi

c. Use Case Diagram Laporan

Pada Use Case Diagram Laporan terdapat beberapa laporan yang dapat diambil yaitu: laporan produk terlaris, laporan pesanan, laporan stok barang, laporan pengiriman dan laporan pendapatan, yang dapat dilihat pada gambar 8 berikut ini.

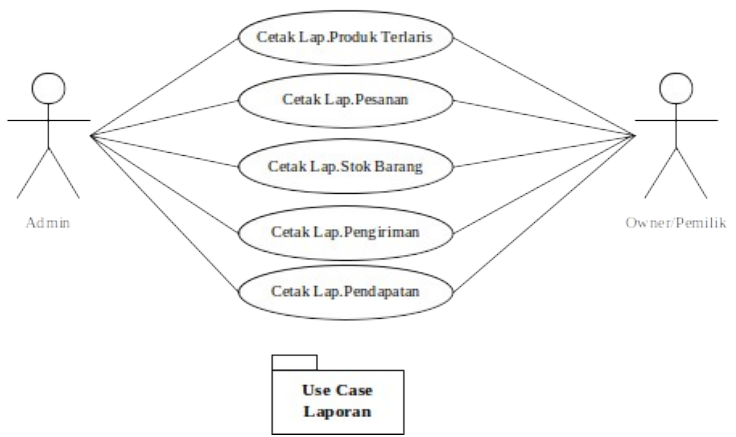

Gambar 8. Use Case Diagram Laporan

\subsection{Model Domain Data Menggunakan Class Diagram}

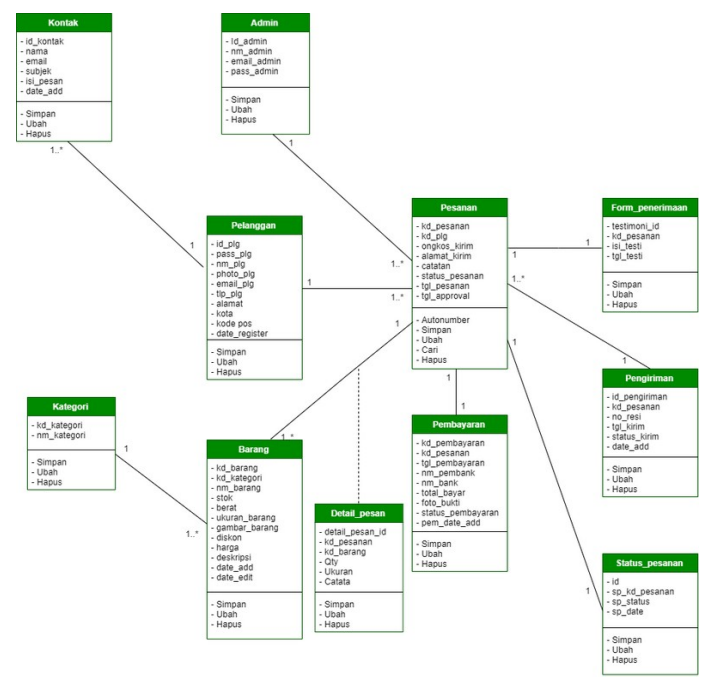

Gambar 9. Class Diagram 
Terdapat 11 (sebelas) kelas yang terlibat dalam perancangan sistem E-Commerce pada Toko XYZ Collection, yaitu: kelas pelanggan, kelas admin, kelas kontak, kelas pesanan, kelas form_penerimaan, kelas pengiriman, kelas pembayaran, kelas kategori, kelas barang, kelas detil_pesan, kelas status_pesanan. Adapun model domain data yang dibutuhkan dalam implementasi sistem E-Commerce Toko XYZ Collection dapat dilihat pada gambar 9.

\subsection{Struktur Tampilan Menu}

Pada gambar ini menjelaskan tampilan menu pada implementasi E-commerce yang diusulkan pada Toko XYZ Collection dapat dilihat pada gambar 9 berikut ini.

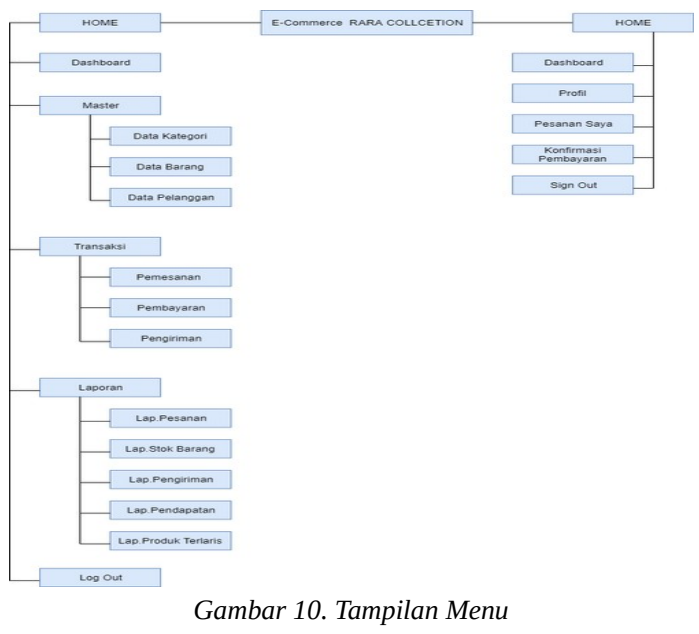

\subsection{Model Perilaku Menggunakan System Sequence Diagram}

Berikut ini adalah model interaksi antara aktor dan sistem yang terjadi pada proses entry pesanan yang digambarkan menggunakan system sequence diagram. Model tersebut dapat dilihat pada gambar 11 berikut ini.

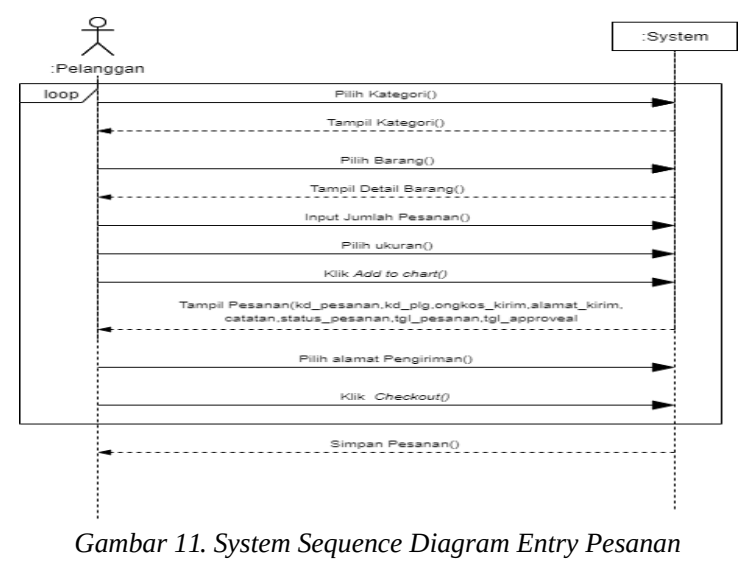

\subsection{Implementasi Sistem}

a. Tampilan Halaman Detail Pesanan
Berikut ini merupakan tampilan halaman detail pesanan pada Toko XYZ Collection dapat dilihat pada gambar 12 berikut ini.

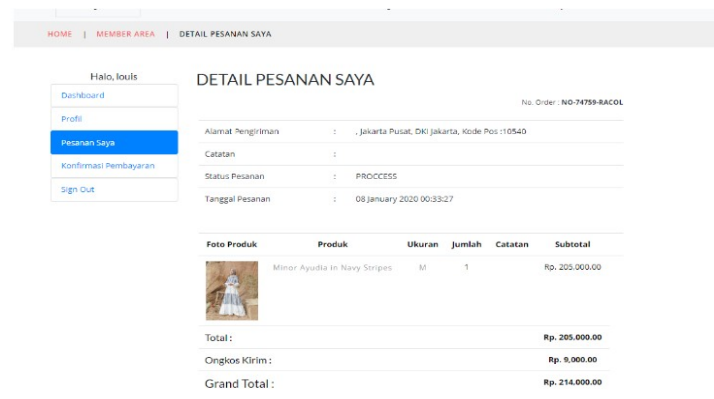

Gambar 12. Tampilan Halaman Detail Pesanan

b. Tampilan Halaman Pemesanan

Gambar 13 merupakan tampilan pemesanan barang yang ada pada Toko XYZ Collection.

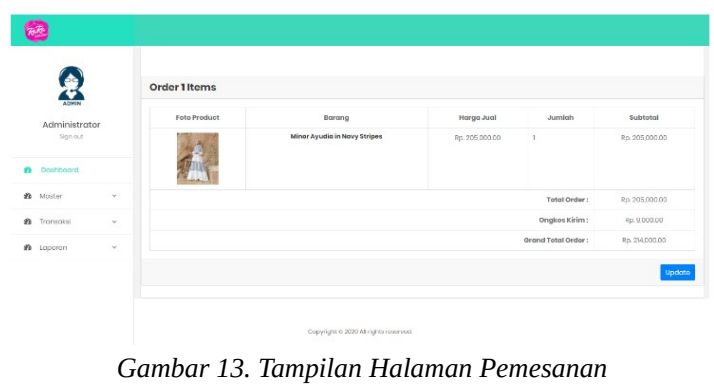

c. Tampilan Laporan Pemesanan

Gambar 14 merupakan tampilan laporan pemesanan yang diimplementasikan pada Toko XYZ Collection

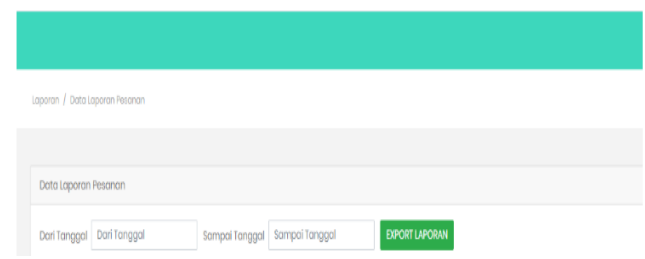

Gambar 14. Tampilan Laporan Pemesanan

\subsection{Hasil Keluaran Program}

Berikut merupakan hasil keluaran program pada Toko XYZ Collection.

a. Laporan Pemesanan

Gambar 14 menerangkan keluaran dari laporan pemesanan pada Toko XYZ Collection. 


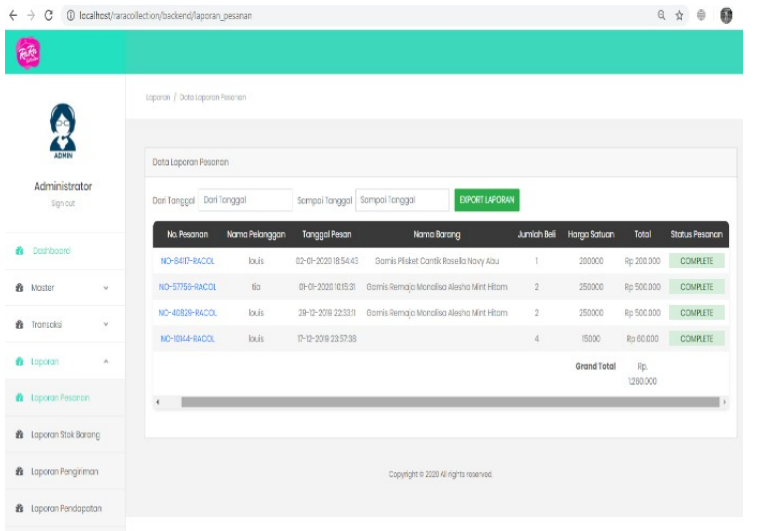

Gambar 15. Keluaran Laporan Pemesanan

b. Laporan Pengiriman Barang

Gambar 16 berikut ini menjelaskan hasil keluaran dari laporan pengiriman pada Toko XYZ Collection.

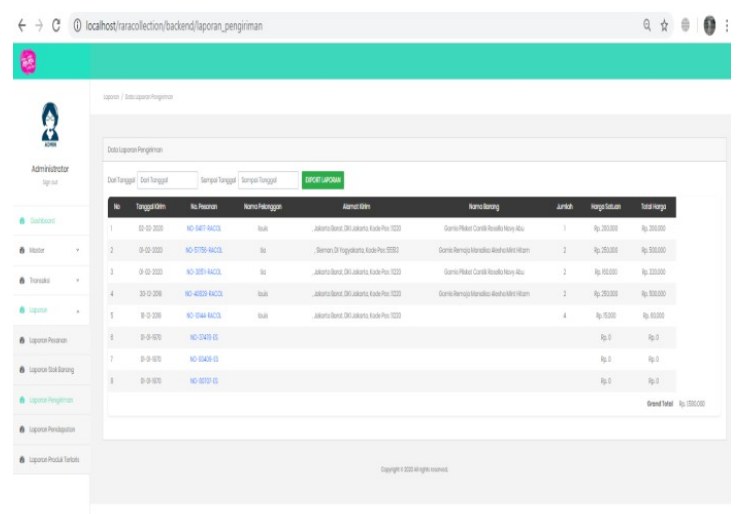

Gambar 16. Keluaran Laporan Pengiriman

\subsection{Implementasi Search Engine Optimization} (SEO)

Gambar 17-23 merupakan hasil implementasi Search Engine Optimization (SEO) pada Toko XYZ Collection:

a. Screenshot Meta Title, Meta Name dan Meta Description.

Gambar 17 merupakan penggalan kode program untuk implementasi Search Engine Optimization (SEO).

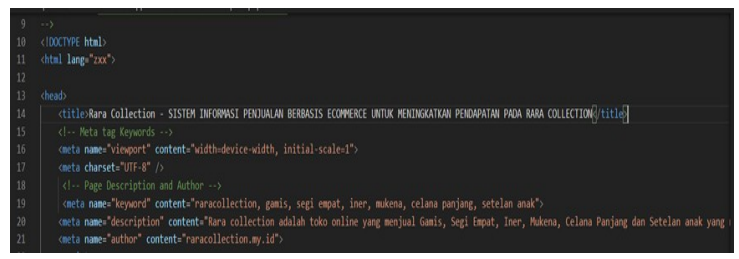

Gambar 17. Meta Title, Meta Name dan Meta Description.

b. Membuat sitemap.xml/sitemap link pada domain website.
Gambar 18 merupakan pembuatan link sitemap.xml/sitemap.

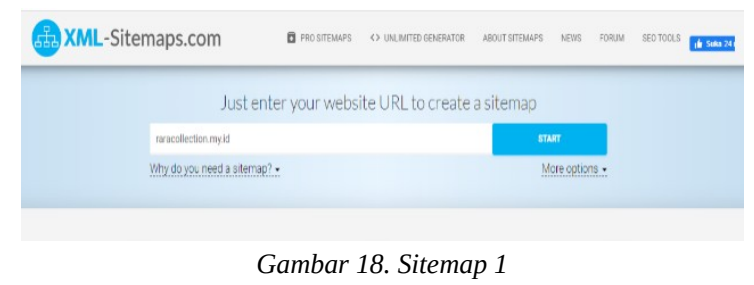

c. Sitemap generator untuk mengcrowl seluruh halaman domain

Gambar 19 merupakan pengaturan sitemap generator.

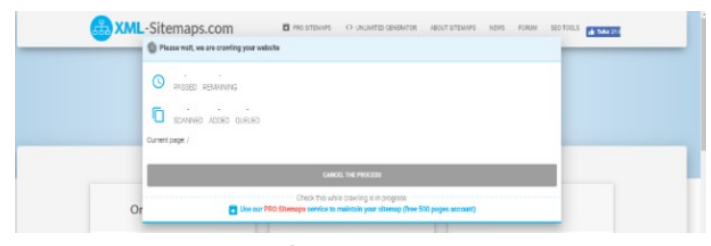

Gambar 19. Sitemap 2

d. Sitemap generator menampilkan button untuk mendownload semua file sitemap.xml .

Gambar 20 merupakan pengaturan sitemap generator.

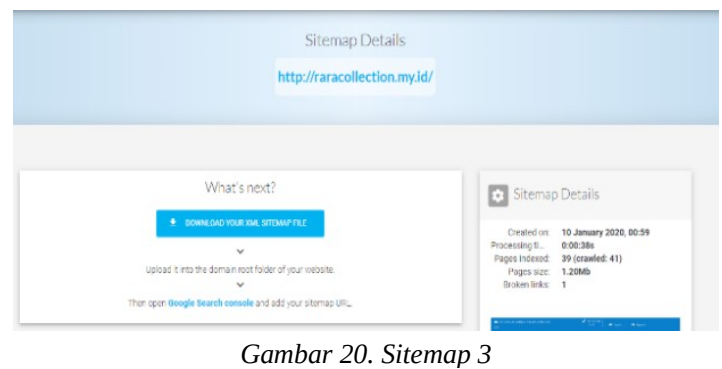

e. Melakukan pendaftaran domain ke Google search console, Seperti pada gambar:

Gambar 21 merupakan proses pendaftaran domain ke google search console.

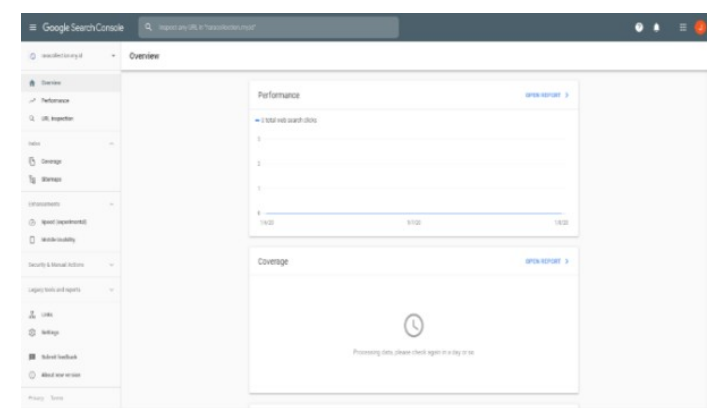

Gambar 21. Google Search Console

f. Tampilan pencarian di Google Search

Gambar 22 merupakan tampilan halaman google search. 


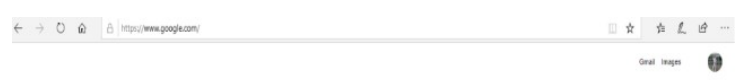

\section{Google}

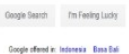

Gambar 22. Google Search

g. Hasil pencarian Google Search

Gambar 23 merupakan contoh pencarian di halaman google search.

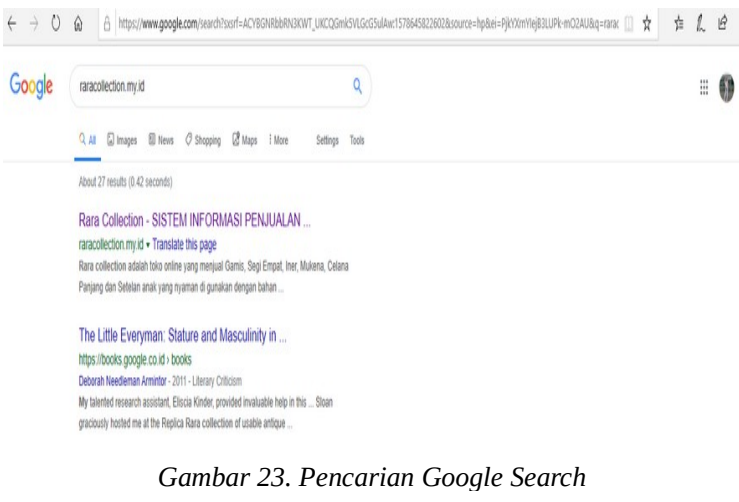

\subsection{Strategi Pemasaran (Marketing)}

Untuk memantau pertumbuhan startup dalam perkembangan pemasaran pada Toko XYZ Collection ini, maka peneliti menggunakan strategi AARRR Framework. Namun hanya komponen Acquisition dan Activation saja yang digunakan, sedangkan komponen Revenue, Retention dan Referral tidak digunakan dalam penelitian ini. Berikut ini beberapa strategi pemasaran (marketing) yang akan diterapkan dalam rangka meningkatkan penjualan pada Toko XYZ Collection yang dijelaskan pada tabel 3 berikut ini.

Tabel 3. Strategi Pemasaran (Marketing) menggunakan AARRR Framework

\begin{tabular}{ll}
\hline $\begin{array}{l}\text { Komponen AARRR } \\
\text { Framework }\end{array}$ & Strategi Pemasaran (Marketing) \\
\hline $\begin{array}{l}\text { Acquisition } \\
\text { (strategi mendatangkan }\end{array}$ & $\begin{array}{l}\text { menyebarkan produk melalui } \\
\text { pelanggan). }\end{array}$ \\
$\begin{array}{l}\text { Activation } \\
\text { (strategi memicu pelanggan facebook. }\end{array}$ \\
$\begin{array}{l}\text { untuk berkunjung). } \\
\text { meliap calon pelanggan yang ingin } \\
\text { registrasi terlebih dulu. }\end{array}$ \\
\hline
\end{tabular}

Gambar 24 adalah hasil implementasi strategi untuk mendatangkan pelanggan melalui fasilitas promosi produk melalui website E-Commerce dan Facebook (Acquisition).
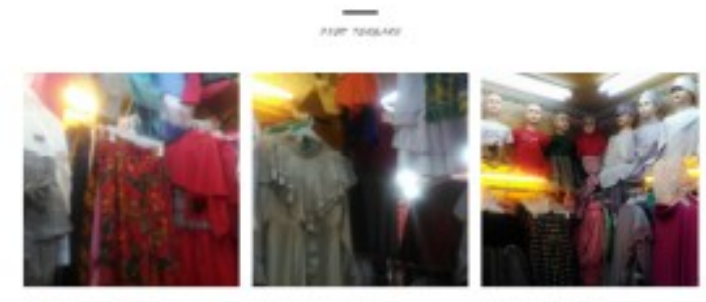

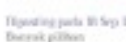
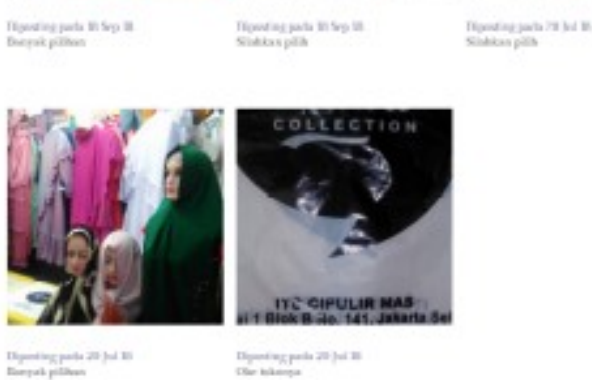

Gambar 24. Strategi Acquisition melalui promosi produk via website E-Commerce dan facebook

Gambar 25 adalah hasil implementasi strategi untuk memicu pelanggan untuk membeli produk (Activation).

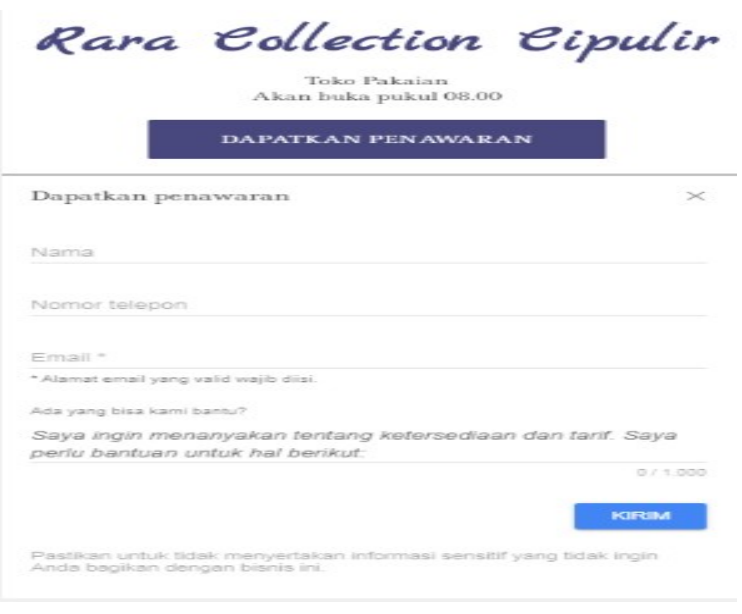

Gambar 25. Strategi Activation dengan Penawaran Harga

\section{KESIMPULAN}

Kesimpulan dari hasil analisis, perancangan dan implementasi E-Commerce pada Toko XYZ Collection adalah sistem penjualan berbasis $e$ commerce ini dapat diakses dimana saja tanpa ada batasan waktu dan tempat sehingga pelanggan tidak perlu lagi datang ke toko, pelanggan juga melihat informasi ketersediaan barang secara langsung di halaman produk, sistem ini juga membantu admin toko dalam melakukan pencatatan laporan penjualan produk dan laporan pendapatan, serta dengan adanya fitur pemasaran, memudahkan pemilik dalam 
melakukan promosi yang ada di aplikasi ECommerce yang terhubung dengan facebook.

\section{DAFTAR PUSTAKA}

[1] S. Zulfah, "Pengaruh Perkembangan Teknologi Informasi Lingkungan (Studi Kasus Kelurahan Siti Rejo I Medan),” Bul. Utama Tek., vol. 13, no. 2, pp. 143-149, 2018, [Online]. Available: https://jurnal.uisu.ac.id/index.php/but/article/view/2 84.

[2] S. S. Utami, "Pengaruh Teknologi Informasi Dalam Perkembangan Bisnis,” J. Akuntasi dan Sist. Teknol. Inf., vol. 8, no. 1, pp. 61-67, 2010.

[3] O. Y. Yuliana, "Penggunaan Teknologi Internet Dalam Bisnis,” J. Akunt. dan Keuang., vol. 2, no. 1, pp. 36-52, 2000, doi: 10.9744/jak.2.1.pp.36-52.

[4] N. Rahmawati and H. Mulyono, "Analisis dan Perancangan Sistem Informasi Pemasaran berbasis Web pada Toko Billy,” J. Manaj. Sist. Inf., vol. 1, no. 2, pp. 104-116, 2016, [Online]. Available: http://jurnalmsi.stikom-db.ac.id/index.php/jurnalmsi/ article/view/44/38.

[5] S. Mumtahana, Hani Atun, Nita and A. W. Tito, "khazanah informatika Pemanfaatan Web ECommerce untuk Meningkatkan Strategi Pemasaran,” Pemanfaat. Web E-Commerce untuk Meningkat. Strateg. Pemasar., vol. 3, no. 1, pp. 615, 2017, [Online]. Available: http://journals.ums.ac.id/index.php/khif/article/view/ 3309/2784.

[6] Sandy Kosasi, "Perancangan Dan Pemanfaatan ECommerce Untuk Memperluas Pasar Produk Furniture," Semin. Nas. Teknol. Inf. dan Komun. 2015 (SENTIKA 2015) Yogyakarta, 28 Maret 2015 ISSN 2089-9815 Peranc., vol. 2015, no. Sentika, pp. 17-24, 2015.

[7] A. U. Riandika, Dedi dan Hamdani, "Implementasi E-Commerce Dengan Teknik SEO dan Strategi Pemasaran 4P Untuk Meningkatkan Penjualan Produk Aksesoris Motor Pada XYZ Motoshop,” J. Media Inform. Budidarma, vol. 4(3), 2020.

[8] D. W. Ariani, Pengendalian Kualitas Statistik (Pendekatan Kuantitatif Dalam Manajemen Kualitas). Yogyakarta: Andi Press, 2004.

[9] F. Royan, Bisnis Model Kanvas Distributor. Jakarta: PT. Gramedia, 2014.

[10] Nugroho Adi, Rekayasa Perangkat Lunak Berbasis Objek Dengan Metode USDP. Yogyakarta: Andi Press, 2010.

[11] K. Hernawati, "Optimalisasi Seo (Search Engine Optimizer) Sebagai Upaya Meningkatkan Unsur Visibility Dalam Webometric,” Optim. Seo (Search Engine Optim. Sebagai Upaya Meningkat. Unsur Visibility Dalam Webometric, pp. 1198-1209, 2009.

[12] Patric, "The AARRR Metric Model," 2018. https://www.metriq.io/blog/aarrr-metric-model (accessed Jun. 24, 2020). 